\title{
How Did Canada's Increasing Lentil Production Affect Turkey? Is There A Possible Win-Win Situation for Both Countries?
}

\section{Cevher Özden*}

The Department of Agricultural Economics, Faculty of Agriculture, Cukurova University, 01330 Adana, Turkey

\section{A R T I C L E I N F O}

\section{Research Article}

Received 06 February 2018

Accepted 08 August 2018

Keywords:

Lentils

Foreign trade

Competition

Sustainability

Constant market share

A B S T R A C T

\begin{abstract}
Competition is fierce in the world markets of agricultural products. It is especially harder for developing countries to compete with the wealthier industrialized countries. Canada entered in the lentil production mainly for export purposes in the early 1990s and exports nearly all of its lentil products every year. As Canada has become the dominant power in lentil trade, Turkey's lentil production has declined notably. In the study, Turkey's adaptation to this trend is investigated. Based on the results, it is concluded that Turkey's market share has not changed in its traditional markets and its export has risen both in quantity and value. For instance, Turkey's lentil export has increased from 127 Thousand tons in 1997 to 178 Thousand in 2013. This is achieved through partnerships between Canadian and Turkish entrepreneurs. Furthermore, lentil producers in Turkey have shifted to alternative crops, which yields higher income.
\end{abstract}

*Corresponding Author:

E-mail: efeozden@gmail.com

DOI: https://doi.org/10.24925/turjaf.v6i12.1708-1712.1840

\section{Introduction}

Countries, producing the same type of products, are in an intense competition in all sectors. This is especially evident in agriculture sector because plantation and harvest periods of the same product could be different in distinct parts of the world, which enables close monitoring of production decisions, yield and policies of rival countries. Archeological evidence suggests that pulses were first cultivated in the Mesopotamia region between Euphrates and Tigris, which is located between Turkey, Syria and Iraq (AGT, 2017). Therefore, each pulse crop is an important food product produced and consumed throughout this region. Lentil, a pulse product, is also a traditional export item for Turkey, Syria and Iran in this region.

Turkey became leader pulse producer and exporter during 1980s thanks to the heavy agricultural subsidies. This situation changed in the early 1990s when Turkey's transition to free market economy gained momentum. Limited economic sources of Turkey were not able to support industrialization and heavy agricultural subsidies at the same time (Ozden, 2015). In accordance with the radical economic decisions adopted following the severe economic crisis in 1994, agricultural supports and guarantee of government purchase were abolished for certain products including lentils. Furthermore, obligations assumed in General Agreement on Tariffs and

Trade (GATT) and World Trade Organization (WTO) agreement required the liberalization of agricultural trade, which necessitated Turkey to take steps to reform the agriculture sector. Canada, Australia and USA started to increase their lentil production as of late 1980s and early 1990s, which increased competition in lentil trade. In Turkey, Inward Processing Regime (IPR) entered into force in place of Export Support Regime (ESR) in 1996. Turkey started to implement IPR fully in 1997 (Deloitte, 2017). The aim of Inward Processing Regime is to enable exporters to supply inputs at the world market prices for the production of their exports without being subject to customs duties, including Value Added Tax as well as trade policy measures (YOIKK, 2017). Turkey included lentil in this framework and started to export lentils primarily from Canada and re-export them to Middle East and Africa with the intent of sustaining its position in lentil trade. In a recent report, the Union of Turkish Agricultural Chambers (UTAC, 2018) has reported that Turkish lentil producers do not earn enough to cover their expenses, therefore, approximately $80 \%$ of lentils consumed in Turkey are imported mainly from Canada, and Turkey's lentil productions are mostly exported to developed countries due to its better taste and high protein content. In his PhD thesis, Ozden (2015) investigated the history of pulse markets and export competitiveness of 
Turkey and proposed certain policy changes. Gandhi (2006) underlined the importance of Asian countries in pulse trade and expected that India's import of pulse products would continue to increase in the future. Ton et al. (2013) analyzed the structure and problems of pulse production in Turkey. They concluded that the real potential of Turkey is not utilized enough. They proposed that new species should be developed to meet the demands of foreign markets and producers should be supported with certain incentives. The previous studies mainly dwell upon the policies to increase domestic production and protect Turkish producers against imports from foreign countries. However, this is not a sustainable approach especially for developing countries with limited economic sources. In this regard, the main question examined in the current study is "How Canada's increasing lentil production affected Turkey's lentil producers and exporters". The subject is especially important in that Canada is an industrialized G7 country with broad economic strength, while Turkey is a developing country with relatively limited economic resources. The results will provide guidance for developing countries to find their own ways in dealing with the intense competition in the world markets especially with developed and wealthier countries.

\section{Materials and Methods}

Production and trade statistics were obtained from FAO and TSI databases. In addition, the publications of prominent organizations and unions active in lentils sector were used. In order to analyze Turkey's lentil trade, Constant Market Share (CMS) analysis was employed. CMS is mainly used to inspect the changes in a country's export performance for certain markets and periods and it explains the transformation with three components, (1) Market Share Effect, (2) Commodity Composition Effect, and (3) Commodity Adaptation Effect (Erlat and Erlat, 2012; Foresti, 2004):

$$
\begin{aligned}
& S_{i j}=\frac{X_{i j}}{\sum_{i=1}^{N} M i j}=a_{i j} b_{i j} \\
& a_{i j}=X_{i j} / M_{i j} \\
& b_{i j}=M_{i j} / \sum_{i=1}^{N} M_{i j}
\end{aligned}
$$

$X_{i j}$ : Country a's export of commodity $\mathrm{i}$ to country $\mathrm{j}$,

$M_{i j}$ : Country j's import of commodity i,

$S_{i j}$ : Market share of country a's export of commodity $\mathrm{i}$ in country j's imports,

$a_{i j}$ : Commodity share of country a's export of commodity $i$ in country $j$ 's import of $i$

$b_{i j}$ : commodity share of $\mathrm{i}$ in country j's import,

the change between time " 0 " and " 1 " is defined as follows:

$$
\Delta S_{i j}=S_{i j}^{1}-S_{i j}^{0}=a_{i j}^{1} b_{i j}^{1}-a_{i j}^{0} b_{i j}^{0}
$$

The equation can be broadened as:

$$
\Delta S_{i j}=\left(a_{i j}^{l}-a_{i j}^{0}\right) b_{i j}^{0}+a_{i j}^{0}\left(b_{i j}^{l}-b_{i j}^{0}\right)+\left(a_{i j}^{l}-a_{i j}^{0}\right)\left(b_{i j}^{l}-b_{i j}^{0}\right)
$$

In the last equation, $S_{i j}$ is divided in three components, which are:

Market Share Effect $\left[\left(a_{i j}^{1}-a_{i j}^{0}\right) b_{i j}^{0}\right]$ : indicates the effect of changes in micro shares of country a

Commodity Composition Effect $\left[a_{i j}^{0}\left(b_{i j}^{1}-b_{i j}^{0}\right)\right]$ : indicates whether country a has concentrated on the export of rapidly growing commodities

Commodity Adaptation Effect $\left[\left(a_{i j}^{1}-a_{i j}^{0}\right)\left(b_{i j}^{1}-\right.\right.$ $\left.b_{i j}^{0}\right)$ ]: indicates the adaptability of country a to the changes in commodity composition of the target market.

\section{Results}

World lentil production increased from 2.7 million tons in 1997 to 4.8 million tons in 2014. In the same period, world lentil harvest area increased from 3.4 million ha to 4.5 million ha. Despite the increasing world production, Turkey's lentil production decreased from 515 thousand tons to 345 thousand tons (Table 1). In the same period, Canada's lentil production leaped from 380 thousand tons to 2 million tons. On the other hand, India with $40 \%$ of world lentil harvest area still has difficulty in meeting internal demand, and needs to import lentil (FAO, 2017).

Turkey's and Canada's lentil production followed a close path until 2006, however, this pattern swiftly changed as of 2007. Canada's production greatly increased, while Turkey's production decreased to some degree (Figure 1). And, Canada became the biggest lentil producers in the world by providing $41 \%$ of world lentil production alone in 2014 (FAO, 2018). Turkey provided $7 \%$ of world lentil production and it was still the third biggest producer country in the world.

World lentil import increased from 836 thousand tons in 1997 to 2.5 million tons in 2013 (Table 2). This was caused by the increasing lentil imports of India, Bangladesh, Turkey and UAE (FAO, 2017). Similarly, Turkey's lentil import increased from 81 thousand tons to 220 thousand tons in the same period. The main reason was the Inward Processing Regime (IPR) Turkey put into force in 1996.

Canada exported 301 thousand tons of lentils in 1997, and it was the biggest lentil exporter, providing $37 \%$ of world lentil export. It was followed by Syria, India Turkey. In 2013, Canada exported 1.8 million tons of lentils and provided $68 \%$ of world total. It was followed by Australia, USA and Turkey. Turkey's lentil export significantly increased in this period. On the other hand, Canada exported nearly all of its lentil production in 2013. This indicates that Canada produces lentils only for export purposes, which is a rare situation seen in agriculture. 
Table 1 Lentil production and harvest area in the world and important countries*

\begin{tabular}{|c|c|c|c|c|c|c|c|c|c|}
\hline \multirow{3}{*}{ Countries } & \multicolumn{4}{|c|}{1997} & \multirow{3}{*}{ Countries } & \multicolumn{4}{|c|}{2014} \\
\hline & \multicolumn{2}{|c|}{ Production } & \multicolumn{2}{|c|}{ Area harvested } & & \multicolumn{2}{|c|}{ Production } & \multicolumn{2}{|c|}{ Area harvested } \\
\hline & (tones) & $(\%)$ & (ha) & $(\%)$ & & (tones) & $(\%)$ & (ha) & $(\%)$ \\
\hline India & 962.000 & 34.9 & 1.369 .400 & 39.8 & Canada & 1.987 .000 & 41.2 & 1.217 .100 & 26.9 \\
\hline Turkey & 515.000 & 18.7 & 560.000 & 16.3 & India & 1.100 .000 & 22.8 & 1.800 .000 & 39.8 \\
\hline Canada & 378.800 & 13.8 & 329.000 & 9.6 & Turkey & 345.000 & 7.1 & 243.370 & 5.4 \\
\hline Bangladesh & 170.505 & 6.2 & 206.347 & 6.0 & Nepal & 226.830 & 4.7 & 205.939 & 4.6 \\
\hline Nepal & 124.420 & 4.5 & 158.270 & 4.6 & Austr. & 238.120 & 4.9 & 162.400 & 3.6 \\
\hline USA & 108.450 & 3.9 & 69.610 & 2.0 & USA & 156.310 & 3.2 & 104.810 & 2.3 \\
\hline World & 2.752 .651 & 100 & 3.439 .136 & 100 & World & 4.827 .122 & 100 & 4.524 .043 & 100 \\
\hline
\end{tabular}

Table 2 Lentil imports in the world*

\begin{tabular}{l|rr|l|rr}
\hline & \multicolumn{2}{|c|}{1997} & & \multicolumn{2}{|c}{2013} \\
\cline { 2 - 3 } & tons & & tons & \multicolumn{2}{c}{$\%$} \\
World & 836.490 & 100.0 & World & 2.508 .623 & 100.0 \\
Sri Lanka & 83.186 & 9.9 & India & 679.662 & 27.1 \\
Turkey & 81.324 & 9.7 & Bangladesh & 219.603 & 8.8 \\
Egypt & 76.582 & 9.2 & Turkey & 199.476 & 8.0 \\
Colombia & 54.979 & 6.6 & UAE & 186193 & 7.4 \\
Spain & 46.904 & 5.6 & Sri Lanka & 151.129 & 6.0 \\
\hline
\end{tabular}

*Source: FAO

Table 3 Lentil exports in the world*

\begin{tabular}{|c|c|c|c|c|c|}
\hline & \multicolumn{2}{|c|}{1997} & & \multicolumn{2}{|l|}{2013} \\
\hline & tons & $\%$ & & tons & $\%$ \\
\hline World & 806.275 & 100.0 & World & 266.4668 & 100.0 \\
\hline Canada & 300.846 & 37.3 & Canada & 180.6336 & 67.8 \\
\hline Syrian & 133.588 & 16.6 & Australia & 316.740 & 11.9 \\
\hline India & 130.728 & 16.2 & USA & 210.816 & 7.9 \\
\hline Turkey & 127.150 & 15.8 & Turkey & 178.542 & 6.7 \\
\hline
\end{tabular}

*Source: FAO

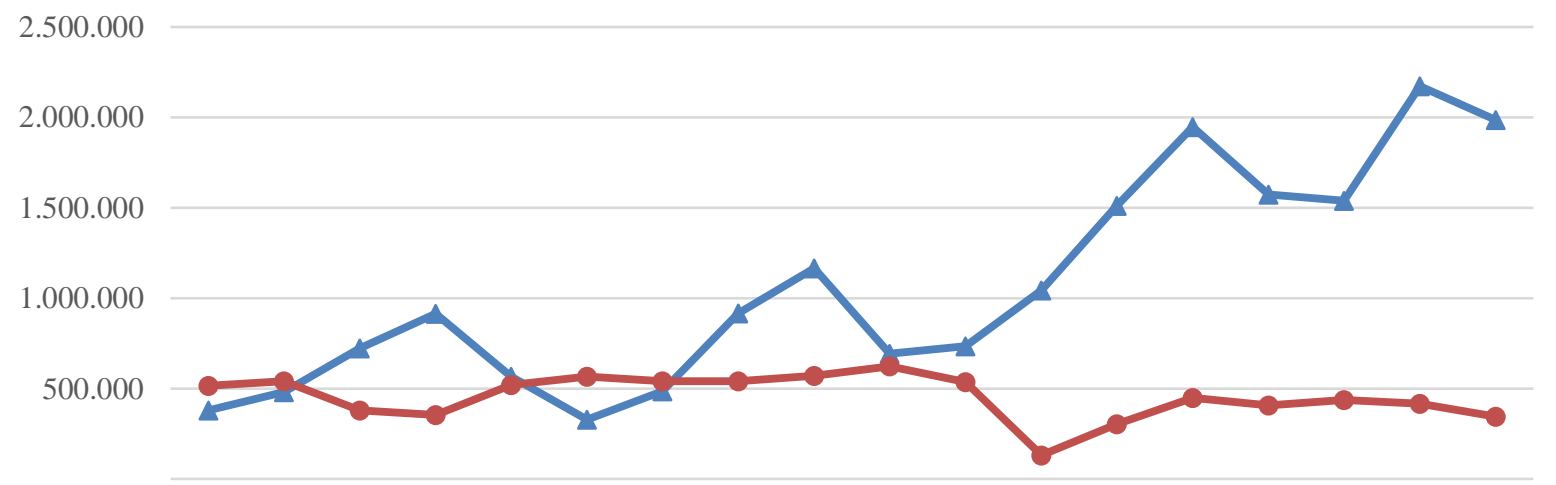

199719981999200020012002200320042005200620072008200920102011201220132014

$$
\longrightarrow \text { Canada } \longrightarrow \text { Turkey }
$$

Figure 1 Lentil productions in Canada and Turkey

Turkey is an important player in all aspects of lentil from production to export and import. It makes significant amount of lentil import every year under IPR framework for the purpose of re-export them. For this reason, despite its lowering production, Turkey's lentil export increased in the study period, which is another rare situation for agriculture. In order to analyze how Canada's increasing performance in lentil affected Turkey's sector, we carried out Constant Market Share analysis for period between
1997 and 2013. The main aim in this analysis is to identify how a country's presence in certain markets has changed in time and the driving forces effective in this change. For this purpose, we first determined the important markets for Turkey's lentil exporters for 1997 and 2013. Accordingly, Egypt, Germany, Iraq, Israel, Saudi Arabia, Sri Lanka and United Kingdom (UK) were detected through investigating the detailed trade matrices of FAO (FAO, 2017). 
Table 4 Results of constant market share analysis for the period of 1997-2013

\begin{tabular}{l|cccc}
\hline & Market Share Effect & Commodity Composition Effect & Commodity Adaptation Effect & Total Change \\
\hline Egypt & -0.0006921 & -0.0009098 & 0.0004622 & -0.0011397 \\
Germany & 0.0000046 & -0.0000017 & -0.0000015 & 0.0000014 \\
Iraq & -0.0000020 & 0.0005194 & -0.0000033 & 0.0005140 \\
Israel & -0.0000161 & -0.0000422 & 0.0000080 & -0.0000503 \\
Saudi Arabia & -0.0000830 & -0.0000530 & 0.0000281 & -0.0001078 \\
Sri Lanka & -0.0006417 & -0.0002161 & 0.0002151 & -0.0006426 \\
UK & -0.0000047 & 0.0000045 & -0.0000015 & -0.0000017 \\
\hline
\end{tabular}

MSE: Market Share Effect, CCE: Commodity Composition Effect, CAE: Commodity Adaptation Effect

Table 5 Wheat, maize and cotton harvest areas*

\begin{tabular}{l|lrrr}
\hline \multirow{3}{*}{1997} & & Wheat & Maize & Cotton \\
& Turkey (ha) & 93.400 .0 & 5.450 .0 & 7.217 .0 \\
& Southeast Anatolia (ha) & 11.211 .0 & 67.0 & 1.2 \\
\multirow{3}{*}{2016} & Share (\%) & 12.0 & 6.800 .0 & 35.7 \\
& Turkey (ha) & 76.719 .0 & 1.703 .0 & 4.160 .0 \\
& Southeast Anatolia (ha) & 11.686 .0 & 25.0 & 2.383 .0 \\
& Share (\%) & 15.2 & 57.3 \\
\hline
\end{tabular}

*Source: TSI

The results of CMS analysis showed that Turkey's market share slightly decreased in Egypt, Israel, Saudi Arabia, Sri Lanka and United Kingdom, while it was slightly improved in Germany and Iraq (Table 4). Both changes were low and non-significant, which indicated that Canada's massive increase in production and export did not affect Turkey's lentil export at all. Turkey maintains its critical position in lentil world trade thanks to its lentil imports within IPR framework, and this implies that Turkish exporters have not suffered a significant loss.

The main reasons could be attributed to the imports and re-exports of lentils carried out by Turkish exporters under IPR framework. Turkish exporters gained valuable experiences in the long history of lentil production and trade of Turkey, especially during late 1970s and 1980s. They import lentils primarily from Canada and re-export them to Middle East and Africa. Canada produces lentils mainly for export purposes and is relatively less experienced. Therefore, the experience of Turkish exporters has become their most vital capital. They built up partnership with Canadian producers and traders and even established their own processing facilities in Canada. Lentil is a relatively new and unusual crop for Canada. In fact, lentil consumption is quite low in Canada. Therefore, Turkey's experience and knowledge background provided guidance to Canada, and the presence of Turkish exporters in Canada prevented possible problems that could have occurred in processing and consumer demands.

\section{The Situation of Turkish Lentil Producers}

So far, we tried to understand the situation from exporters' aspect, but Turkey's lentil production decreased anyhow, and this should have certain implication for Turkish producers. In this section of the study, first, Turkey's prominent lentil producer provinces were determined through analyzing TSI database (Figure 2). Accordingly, in 1997, Turkey's 430 thousand ha lentil harvest areas are distributed among Sanliurfa (33.2\%), Diyarbakir (26.8\%), Mardin (16.8\%), Gaziantep (7.5\%), Sirnak (3.7\%), Kilis (3.5\%), Batman (2.7\%), Adiyaman $(2.4 \%)$ and Siirt $(2.0 \%)$. All of these provinces are located in the Southeastern Anatolia Region of Turkey. Similarly, in 2013, Turkey's 230 thousand ha lentil harvest areas were mainly found in Sanliurfa $(45.0 \%)$, Diyarbakir (23.1\%), Mardin (13.1\%), Batman (5.7\%), Siirt (2.7\%) and Adiyaman (2.1\%) (TSI, 2017).

There is no big difference between 1997 and 2013 in terms of the region; however, harvest area has declined nearly to half in many provinces. The main reasons for farmers to quit lentil production are determined as follows:

Irrigated land areas have expanded with the Southeastern Anatolia Project (SAP). Out of 22 dams and 19 hydroelectric power plants, 19 dams and 13 hydroelectric power plants have been constructed and are fully functional at present. By the end of 2015, a total of 475.528 ha lands were opened for irrigated farming and the construction of supply network that can irrigate another 160.000 ha lands are in progress GAP, 2017).

Irrigated farming enables to produce more profitable crops that are also suitable for mechanized farming, which will reduce labor costs, as well. Turkey is under effect of climate change like the whole world, and lentils are easily affected by drought and heavy rain ruins the quality and yield of lentils.

Due to the high input costs, domestic lentil price occurs over international prices, and Turkish farmers struggle to compete with the imported product in the domestic market, and farmers abandon lentil production.

However, substantial amount of lentils are still produced in the Southeast Anatolia Region of Turkey. However, producers have mostly shifted to maize, wheat and cotton productions. Cotton is a valuable industry crop, and more than half of Turkey's cotton production $(57.3 \%)$ is carried out in the Southeast Anatolia. In addition, maize production has increased to around 25- 
fold between 1997 and 2014, which has also increased Turkey's maize export by 18 -fold. This brought about important financial gains both for farmers and Turkey.

Turkey must stop its declining trend in lentil production and should produce at least sufficient amounts of lentils to meet the domestic demand and take measures to prevent importation for domestic use in order to protect its own producers. Turkey has made certain achievement in the development of lentil species that are easier to harvest and grow. Farmers should be encouraged to use these species, and agricultural extension activities should be carried out for this purpose. There are evident differences in the quality and taste characteristics of lentils produced in Canada and Turkey. Lentils grow at 18 ${ }^{0} \mathrm{C}$ in Canada and $35{ }^{\circ} \mathrm{C}$ in Turkey, and taste and protein content of lentils improve depending on the sunshine duration and heat. In this regard, Turkey should invest in Turkish Lentil brand and should develop marketing strategies especially in wealthier countries as it would be more difficult to compete with developed counties in markets with low purchasing power.

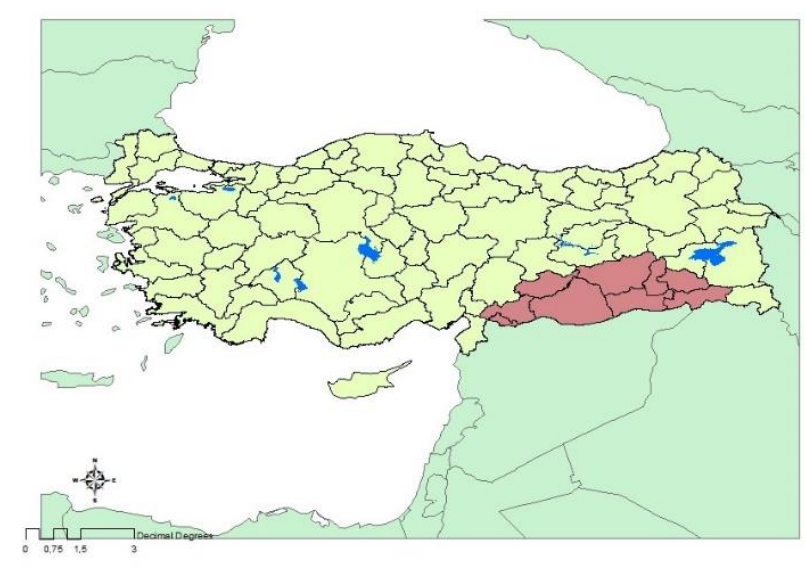

Figure 2 Lentil Harvest Areas in Turkey (Wholly concentrated in the Southeast Anatolia Region)

\section{Alternative Crops to Lentil}

From TSI database, it was detected that cotton and wheat were harvested in the initial years in place of lentil in the Southeastern Anatolia Region of Turkey; however, cotton harvest has slightly declined in the recent years, while wheat and especially maize production have radically increased (TSI, 2017). The abovementioned provinces accounted for $12.0 \%$ of Turkey's wheat harvest area in 1997, while this rate has risen up to $15.2 \%$ in 2016. In a similar way, the Southeastern region had $1.2 \%$ of Turkey's maize harvest area in 1997, and it has jumped to $25.0 \%$ in 2016 . The same rate increased from $35.7 \%$ to $57.3 \%$ for cotton, as well (Table 5).

\section{Conclusions}

The study has mainly dealt with the transformation in Turkey caused by Canada's rising lentil production. And it is concluded that Turkey has not suffered an important loss in its lentil export markets despite the rising production and exportation of Canada thanks to the increased efforts of Turkish exporters operating in Canada and other countries and producing changing their product composition. However, the decreasing trend in lentil production must be stopped so that traditional lentil producers should be supported and encouraged to use newly developed and more resistant lentil species which are easier to harvest and produce higher yield.

Companies of Turkey origin are quite effective in world trade of lentils, especially Mersin province of Turkey is one of the centers in this trade. Thanks to this experience and influence, Turkey's lentil export increased from 79 million \$ to 168 million \$ between 1997 and 2013 and gave 40 million $\$$ of trade surplus. In this regard, Turkish exporters should be supported in their cooperation operations.

The main limitation of this study is to collect information from internationally distributed lentil exporters. Further studies can be carried out by using electronic means of communication and collecting more information about their operations and problems.

\section{Conflicts of Interest}

"The author declares no conflict of interest."

\section{References}

AGT. 2017. History of pulses. http://www.agtfoods.com/aboutpulses/history-of-pulses.html [Accessed 23 June 2017]

DELOITTE. 2017 Customs and Foreign Trade in Turkey. http://www.verginet.net/UserFiles/File/ pusula_serisi/customs(1).pdf [Accessed 23 June 2017]

Erlat G, Erlat H. 2012. Foreign trade between Turkey and Middle East countries. Economic Institution of Turkey.

FAO. 2017. Crops Production Database. http://www.fao.org/ faostat/en/\#data/QC [Accessed 15 May 2017].

FAO. 2018. Trade Statistics. http://www.fao.org/ faostat/en/\#data/TP [Accessed 16 May 2017]

Foresti G. 2004. An attempt to explain the Italian export market share dynamics during the nineties. CSG Working Paper n. 47 .

Gandhi PY. 2006. Export Prospects of Seeds. http://www.ffymag.com/admin/issuepdf/Seeds.pdf [Accessed 21 July 2013]

GAP. 2017. Southeastern Anatolia Project, Regional Administration. Statistical Data. http://www.gap.gov.tr/ en/statistical-data-page-28.html [Accessed 27 May 2017]

Ozden C. 2015. Turkish and Global Pulse Markets and Export Competitiveness of Turkey, PhD, Cukurova University, Adana, Turkey.

Ton A, Karaköy T, Anlarsal AE. 2013. Türkiye'de Yemeklik Tane Baklagiller Üretiminin Sorunları ve Çözüm Önerileri. İç Anadolu Bölgesi 1: Tarım ve Gida Kongresi (2-4 Ekim 2013). Niğde Üniversitesi. 8s.

TSI. 2017. Crops Production Statistics. https://biruni.tuik.gov.tr/ bitkiselapp/bitkisel.zul [Accessed 17 May 2017]

YOIKK. 2017. Export Regime in Turkey. http://www.yoikk .gov.tr/detay.cfm?MID=294 [Accessed 18 May 2017]

UTAC. 2018. Biz Kanada mercimeği yiyoruz, zengin ülkeler Türk mercimeği https://www.tzob.org.tr/basin-odasi/ haberler/biz-kanada-mercimegi-yiyoruz-zengin-ulkeler-turkmercimegi\%E2\%80\%A6 [Accessed 5 June 2018] 